\title{
Welfare Mix as a Contested Terrain: Political Positions on Government-Non-profit Relations at National and Local Levels in a Social Democratic Welfare State
}

\author{
Håkan Johansson ${ }^{1}$ - Malin Arvidson ${ }^{1}$ • \\ Staffan Johansson ${ }^{2}$
}

Published online: 23 May 2015

(C) The Author(s) 2015. This article is published with open access at Springerlink.com

\begin{abstract}
As welfare states are increasingly challenged and replaced by welfare mix models, new ideas about the functions of non-profit and voluntary organisations (NPVOs) provoke political conflicts that should be reflected in research. This paper explores the significance of political and ideological dimensions to present changes in the Swedish welfare state regarding NPVOs as welfare services providers. Investigating both national and local level, the study addresses political as well as practical implications of the reframing of NPVOs as service providers rather than being associated with a voice function. The article shows extensive differences between national and local levels as contentious ideological cleavages at national level are dormant in local level politics. Variations in the way relations to NPVOs are structured in practice at local level appear related to factors other than political dimensions. The findings support the development of an analytical framework that reflects political dimensions and allow for empirical focus that includes national and local level politics and practices.
\end{abstract}

Résumé Tandis que les États providence sont plus en plus contestés et remplacés par des modèles de welfare mix, de nouvelles idées sur les fonctions des

Article prepared for the special issue in Voluntas on "Welfare Mix, Hybridity and GovernmentNonprofit Relationships in Post-Modern Welfare States".

Malin Arvidson

Malin.Arvidson@soch.lu.se

Håkan Johansson

Hakan.Johansson@soch.lu.se

Staffan Johansson

Staffan.Johansson@socwork.gu.se

1 School of Social Work, Lund University, Box 23, 22100 Lund, Sweden

2 Department of Social Work, Gothenburg University, Gothenburg, Sweden 
organisations bénévoles et à but non lucratif provoquent des conflits politiques qui devraient se traduire dans la recherche. Cet article étudie l'importance de la dimension politique et idéologique pour les changements actuels de l'État providence suédois concernant les organisations bénévoles et à but non lucratif en tant que prestataires de services sociaux. Menant une enquête aux niveaux national et local, l'étude porte sur les implications politiques et pratiques de la restructuration des organisations bénévoles et à but non lucratif comme prestataires de services, mais évite de les associer à un rôle de parole. L'article montre des différences considérables entre les niveaux national et local tandis que des clivages idéologiques litigieux à l'échelle nationale sont latents dans la politique locale. Les différences dans la façon dont les relations entretenues avec les organisations bénévoles et à but non lucratif sont structurées en pratique au niveau local semblent liées à d'autres facteurs que les dimensions politiques. Les conclusions promeuvent le développement d'un cadre analytique qui reflète les dimensions politiques et tiennent compte d'une orientation empirique comprenant les politiques et les pratiques aux niveaux national et local.

Zusammenfassung Während Sozialstaaten zunehmend von WohlfahrtsmixModellen in Frage gestellt und von diesen ersetzt werden, lösen neue Vorstellungen zu den Funktionen gemeinnütziger und ehrenamtlicher Organisationen politische Konflikte aus, die in der Forschung berücksichtigt werden sollten. Dieser Beitrag erforscht die Bedeutung politischer und ideologischer Dimensionen, um Änderungen im schwedischen Sozialstaat mit Hinblick auf diese Organisationen als Anbieter von Sozialdienstleistungen zu präsentieren. Die Studie untersucht sowohl die nationale als auch die lokale Ebene und befasst sich mit den politischen und praktischen Implikationen der Umgestaltung von gemeinnützigen und ehrenamtlichen Organisationen, um als Dienstleistungsanbieter zu agieren anstatt eine Repräsentationsfunktion auszuüben. Der Beitrag deckt große Unterschiede zwischen der nationalen und der lokalen Ebene auf; denn die umstrittenen ideologischen Klüfte auf der nationalen Ebene sind in der lokalen Politik nur latent vorhanden. Unterschiede in der Art und Weise, in der Beziehungen zu gemeinnützigen und ehrenamtlichen Organisationen in der Praxis auf lokaler Ebene strukturiert sind, scheinen mit Faktoren außerhalb politischer Bereiche zusammenzuhängen. Die Ergebnisse unterstützen die Entwicklung eines analytischen Rahmens, der politische Dimensionen reflektiert, und ermöglichen einen empirischen Schwerpunkt, der die Politik und Praxis auf nationaler und lokaler Ebene berücksichtigt.

Resumen Dado que los estados de bienestar están siendo cada vez más cuestionados y sustituidos por modelos mixtos de bienestar, las nuevas ideas sobre las funciones de las organizaciones voluntarias y sin ánimo de lucro (NPVO, del inglés Non-profit and voluntary organisation) provocan conflictos políticos que deben ser reflejados en la investigación. El presente documento explora la importancia de las dimensiones políticas e ideológicas para presentar los cambios en el estado de bienestar sueco en relación con las NPVO como proveedoras de servicios de bienestar. Al investigar tanto el nivel nacional como el local, el estudio aborda las implicaciones políticas, así como también las prácticas, de la reformulación de las 
NPVO como proveedoras de servicios en lugar de asociarlas a una función de voz. El artículo muestra las grandes diferencias entre los niveles local y nacional, ya que las divisiones ideológicas polémicas a nivel nacional están latentes en la política a nivel local. Las variaciones en la forma en la que están estructuradas las relaciones con las NPVO en la práctica a nivel local aparecen relacionadas con los factores aparte de las dimensiones políticas. Los hallazgos apoyan el desarrollo de un marco analítico que refleje las dimensiones políticas y permita un foco de atención empírico que incluya la política y las prácticas a nivel nacional y local.

Keywords Welfare mix $\cdot$ Ideology $\cdot$ Non-profit organisations $\cdot$ Public service provision

\section{Introduction}

Our present understanding of national welfare mix models is challenged by a complex set of interrelated processes. European welfare states are under pressure to reform social policies and social services. As a result, non-statutory bodies, including non-profit, voluntary organisations, have become important in the catering for citizens' various needs, and in potentially closing the gap when and where the state 'fails to' deliver. In the aftermath of the European financial and economic crisis, politicians are increasingly seeking to involve various types of non-profit and voluntary (NPV) sector organisations to deliver support and welfare services to its citizens (e.g. EESC 2012). Although moves towards embedding these organisations in the welfare state on the basis that they can offer innovative, more cost-effective and client-responsive approaches are not new (Ascoli and Ranci 2002; Bode 2006; Henriksen et al. 2011), a changing financial climate has offered further incentives to do so. At the same time, sub-national arenas, cities and local municipalities have become increasingly important for public policy regulation and social service delivery (Kazepov 2008, 2010). The complex set of problems that many central governments face are seen as best handled at local level, by local politicians and including the enrolment of various types of local stakeholders (Andreotti et al. 2012). A greater reliance on local delivery of welfare and services may however not simply lead to policies and services adjusted to local needs and preferences, but may be seen as a form of 'austerity localism' (Featherstone et al. 2012) that in turn reflect and provoke embedded conflicts and tensions that stem from national party politics as well as local governments.

These trends and developments play out differently across the European continent, and are more contentious and conflict laden in some European welfare states than others. This is certainly so in the context of the Swedish welfare state as it is often seen as the archetype of a Social Democratic welfare state model, in which NPV sector organisations (hereafter NPVOs), as well as market-based forprofit actors, have generally held a marginal position in producing welfare services for the larger population and the main role and function for NPVOs has been to act as political agents, fulfilling an expressive rather than a service-oriented function (e.g. Lundström and Svedberg 2003; Svedberg and Olsson 2010; Wollebeak and 
Selle 2008; Selle and Wollebaek 2010). Albeit Sweden was not struck by recent economic crisis to the same extent as many other European countries, this institutionalized role is currently in flux and observers point to ongoing and gradual shifts 'from voice to service' or 'from members to volunteers' and an increase in professionalization among these organisations (Wijkström and Einarsson 2006; Papakostas 2004; Svedberg and Olsson 2010; Danielsson et al. 2009). We have also seen recent ambitions by Centre-Right governments to promote welfare pluralism and greater diversity of welfare services providers. This suggests that the enrolment of NPVOs is a fairly contested terrain in the Swedish welfare state, mobilizing differences between political parties and affected stakeholders.

This paper seeks to locate the analysis of political dimensions related to NPVOs as service providers to the level where it should be rightfully placed, i.e. at the local level. In many countries - and very much so in the Swedish context-social welfare services are delivered locally, by local actors and hence part of a local political context. What takes place at local level cannot be automatically reduced to national political perceptions and positions on a welfare mix. This gives rise to a set of questions that refer to the difference in political positions between parties at national level, and the bearing these differences have on local politics in practice. Is it the case that, at national level, there is a stronger politicization around welfare reforms than at local level? Is politicization part of a rhetorical culture, practised at national level, whereas we find a more pragmatic, less polarized approach to the implementation of welfare reforms at local level?

The aim of this article is to analyse the significance of a political and ideological dimension to present changes in the Swedish welfare state regarding NPVOs involvement as providers of social services. The article explicitly seeks to analyse differences between national and local levels by asking whether local governments led by a Right-Wing political majority are more inclined to promote a greater local welfare mix and a stronger service provider role for local NPV sector organisations than Left-Wing led municipalities.

To accomplish such an analysis, the article explores two data sets. The first data set is the financial reporting that municipalities send into Statistics Sweden regarding financial payments to voluntary sector organisations in their municipality. In this case, we have used the data for municipalities' grants and purchase of social services within areas such as elderly care, disability care etcetera from local associations and foundations. Data have been collected for all Swedish municipalities and for the years of 2000-2012. ${ }^{1}$ The article also explores data from an original survey conducted with a strategic sample of local authorities in Sweden. The survey was sent to the highest civil servant in local social services

\footnotetext{
1 Sweden has 290 municipalities which all are governed by a locally elected government. A total of 138 municipalities are governed by a Centre-Right coalition which tend to include a combination of representatives from the Conservative Party, The Liberal Party, the Christian Democrats and the Agrarian Party (here referred to as a right-wing government), 109 municipalities are governed by a combination of Left-wing parties (mostly the Social democrats, the Left Party and/or the Green Party) and 43 local governments are governed by a Right-Left coalition, often including the Social Democrats together with the Conservative party, being the two largest parties, but can also include a wide variety of other combinations reflecting local conditions and election behaviour.
} 
(Socialchefer), which we considered the most suitable actors to answer our questions regarding overall local policies vis-á-vis the voluntary sector, and in particular, with regard to the organisation of local welfare production.

The population was selected using Statistics Sweden's categorization of municipalities into ten municipality categories (following mainly size, yet partly also regional matters), randomly selecting $50 \%$ of the municipalities for each category $(N=149)$. The survey was distributed both as a web survey and by paper (ordinary post service) and a total of 89 responses were handed in, however due to e.g. double answers, we ended up having 85 responses giving us a response rate of $57 \%$. Both data sets have been analysed against political majority (Left-Wing, Right-wing and Coalition led local governments) and also other relevant factors, all with the view to identify factors that might explain local variation the role ascribed to voluntary organisations. Although one should be cautious in making generalized conclusions based on such small $\mathrm{N}$, our response rate covers approx. $30 \%$ of all Swedish municipalities.

The article is divided into five sections. The next section presents the welfare mix perspective and recent interest into how ideology might explain national variations on state-voluntary sector relations. The following section analyses political positions on national welfare mix models, followed by an analysis of political positions on local welfare mix models. Investigations cover general policy orientations regarding NPVOs' role as social service providers, more explicit political positions on local funding schemes. The article concludes with a discussion on national and local differences and forms of political and ideological contestations regarding NPVOs' involvement as providers of social services in the Swedish welfare state.

\section{Strands of Welfare Mix Research}

The analytical endeavour to examine a welfare mix started to take off in the late 1980s and the beginning of the 1990s and originated in an implicit critique of classic welfare (state) research (e.g. Evers 1995; Evers and Laville 2004; Ascoli and Ranci 2002, see also Titmuss 1958; Pinker 1992 for the related notions on 'welfare pluralism' and 'mixed economy of welfare'). Whereas welfare state studies to a large extent focused (and still focus) on state, market and family involvement in welfare production and risk coverage (e.g. Esping-Andersen 1990, 1999), the main focus of welfare mix studies has included the role and function of voluntary, nonprofit and third sector actors in domestic welfare production and the delivery of welfare services. Since these academic debates started to emerge, we have seen a stepwise development of this particular research debate into a mature research field covering various themes and orientations.

One dominant theme of research is the extensive interest in what we would like to phrase as studies of national welfare mix models. The studies conducted by Salamon and Anheier and the John Hopkins project are certainly the most prominent examples of such research (Salamon and Anheier 1994, 1996, 1998a, b). They paved the way for international investigations on the role of the non-profit sector in a comparative perspective and even more so extensive discussions on whether we could identify models of non-profit welfare production and what factors could 
explain such variations. Interest into the size, aim and orientation of the non-profit sector (see Evers and Laville 2004; Salamon and Anheier 1997, 1998a; Salamon et al. 2003) developed in correspondence with Esping-Andersen's welfare state regime theory as these authors sought to map 'nonprofit' involvement in various countries as well as the orientation of the non-profit sector. The studies resulted in extensive mapping of various national sector models' orientation regarding the service/expressive orientation of sector organisations, whether national models mainly relied upon volunteers and/or paid staff and studies into the financial basis (e.g. fees, government funding, and philanthropy support) of the activities of nonprofit organisations.

Within this strand of research explanations for national variations have generally been sought in countries' institutional factors (e.g. functioning and orientation of state bureaucracy), the role and orientation of political parties and the status of various socio-economic classes in that particular country. Differences in national ideological traditions and political orientations have informed analyses as size, structure, function and financing of civil society follows ideal-typical logic models coined a Liberal model, a Welfare partnership model, a Social democratic model, a Statist model and a Traditional model (Salamon 2010, p. 191). Despite these references to model differences based on various political ideologies, the possible role of party political agendas has not been analysed to any greater extent. While there are different views as to the role of civil society embedded in political traditions, the question whether these differences are actively articulated and used in policy formulation, is not explored. Rather it is assumed that 'political traditions' represent relatively homogenous nationwide traditions.

The meaning of a political ideological dimension in the context of roles and expectations associated with NPVOs is further explored in a special issue of Journal of Political Ideologies edited by Kendall and Deakin (2010). Here, Strachwitz and Zimmer (2010) challenge the assumption that one political tradition 'fits' one country's civil society system (and implicitly welfare mix orientation). In contrast they find that a variety of political traditions can be influential in shaping and structuring national civil society/welfare mix models implying a complex mix of Liberal, Catholic and Social Democratic traits. The point made here is based on a critique of what hitherto was seen as homogenous and unifying 'blueprints for organizing state-civil society relations' (Kendall and Deakin 2010:223). These relations can vary considerably within nations, and as Strachwitz and Zimmer point out variations can come from different political traditions embedded within one nation and hence form the basis for a welfare mix. Trägårdh (2010) follows a similar line of thought, yet deliberately avoids talking about a limited set of political ideological traditions and instead puts forward that countries rest upon political cultures that go beyond political traditions such as liberalism, social democracy. These two contributions invite us to analyse the relevance of historically embedded sets of ideas, traditions and codified norms: to what extent do they underpin a uniform, nationwide culture, and to what extent do they support variation in welfare, i.e. an inherent welfare mix model?

Other contributions to the special issue pursue a slightly different interpretation of the political/ideological. Exploring the UK context, Kendall (2010) argues that 
government-third sector relations and contracts have primarily been studied in a 'technocratic' fashion. Research into partnership arrangements, contract cultures, management methods etcetera (e.g. Lewis 2005; Steen-Johansen et al. 2011; Bozzini and Enjolras 2012) have significance for understanding present changes and also the complex forms of relations and interactions that take place between public and NPVOs. Kendall rather suggests that also such organisational and governance changes entail a political ideological dimension, although not always easy to detect. Even further he challenges us to think of state-voluntary sector relations as $a$ contested terrain and coloured by a set of contested ideas and positions that are put forward by various stakeholders, both representatives from political parties and organised interest including voluntary sector organisations.

As suggested by Strachwitz and Zimmer, it is important to acknowledge variations between nations, as well as within nations. This is of particular importance in countries where local municipalities have relative independence from national politics. This has been articulated in comparative social service research and scholars have explored the notion of 'welfare municipalities' to highlight diversity defined as variation within the welfare model, across local municipalities (Kröger 2011; Trydegård and Thorslund 2010). Concepts linked to this line of research include 'territorial equality' and 'postcode lottery' (Trydegård and Thorslund 2010), referring to the inherent tension between the overarching aim to offer a 'universal and equitable social service system' (ibid. p 497) and the fact that local municipalities are highly independent. When seeking to analyse local variations they pay tribute to a list of background factors to explain what local governments do, e.g. population size, municipality structure, local government economy and local politics (ibid.). Findings however often suggest that local level politics is foremost driven by practical and pragmatic concerns, rather than reveal considerable ideological disputes. Furthermore, path dependency defined as 'local social policies' rooted in traditions and historical continuity, is attributed a strong role in explaining local variation rather than disputes and contestations originating in present politics.

The studies referred to above offer us a dual conceptualization of political ideologies for the analysis of state-civil society relations, including aspects regarding NPVOs role and function in welfare state contexts. We maintain the importance of having an inclusive definition of political ideological dimension in order to explore welfare mix models: one that acknowledges politics as tradition, i.e. unifying and embedded norms and structures and where conflicts do exist but are largely dormant, as well as an understanding of politics as ideologically contested issues that involve conflicts. While the former rests on embedded political ideological differences, there is no mentioning of political contestations related to the role and expectations of NPVOs, a topic which is emphasized in the latter. In our usage, these definitions do not stand in opposition, but should rather be combined when exploring political and ideological dimensions of local level welfare policies. 


\section{Political Positions and the Welfare Mix Model: A National Perspective}

Policies oriented towards the NPV sector in the Swedish welfare state have undergone changes during the last decades, moving away from a classic Social democratic regime heritage (Wijkström and Lundström 2002; Lundström and Wijkström 1997, 2012). The Swedish model of state-NPV sector relations has first and foremost emphasized interest mobilization/advocacy and the educational functions of NPVOs. These organisations have primarily functioned as collective arenas and actors for channelling claims and ideas from larger group of citizens as well as schools for democracy, based on a long-lasting tradition of so-called popular movements (e.g. the Labour movement, the Women's movement, the Disability movement being a particular type of voluntary sector organisations based on e.g. extensive membership basis, a federative associational structure, e.g. Amnå 2006a, b). These regime ideals have primarily been nurtured by proponents of the Social democratic party, which has maintained that the voluntary sector should have a complementary role and not act as a replacement to publicly run and financed services (Lundström and Wijkström 2012). The main ambition has rather been to sustain the democratic and representative functions of voluntary sector organisations (e.g. Dir. 2005:117 and SOU 2007:66).

However, as the Social democratic government lost the 2006 election and was replaced by a Centre-Conservative Coalition (hereafter 'the Alliance', in office for two consecutive periods, 2006-2010 and 2010-2014) a new agenda on the role of the NPV sector emerged. The Conservative Prime Minister expressed that the foundation for safety and community in a society '... lie in a strong civil society, such as voluntary or sporting movements, churches, corporations, and nonprofit organisations. The solidarity of the public welfare system is a complement to a society increasingly characterized by compassion, responsibility and idealism' (Declaration of government October 2006). Some newly elected Ministers expressed a strong critique of the previous government's policies and argued that there had been ' ... an ideological blindness in Sweden to what the nonprofit sector is contributing and could help with...' and that '...the nonprofit sector has sometimes been neglected, sometimes institutionalized in the state's narrow templates' (Sabuni and Hägglund 2007). These statements hence suggest a conflict between public and non-profit, voluntary sector involvement and it soon became clear that the CentreConservative government sought to develop policies that aimed to develop ' ... a greater diversity...' of service providers to give patients and care takers the best possible care and services (Declaration of Government October 2006). This aim to foster a greater diversity of service providers had implications for the terminology used as well as for direct policy proposals.

First, the Centre-Conservative agenda on the NPV sector entails a conceptual reorientation away from a Social democratic popular movement tradition. Previous Social democratic governments had much favoured the notions of a 'voluntary sector' or 'popular movement', yet the Centre-Conservative choose to use the term civil society as a more encompassing notion (Reuter et al. 2012). The government's attempt at conceptual innovation is apparent in the title of the government bill, titled 
'A policy for the civil society' (prop. 2009/2010:55) and the government proposed that the term 'civil society' better reflected changes already taking place in the sector as it now increasingly embraced actors following a traditional associational logic, but also social economy organisations and actors running ordinary businesses (prop. 2009/2010:55, p. 47). Furthermore, the aim was most likely to overcome previously established barriers between 'voice' and 'service' oriented functions that remained strongly embedded in the national model. This conceptual re-orientation was partly a response to lobbying activities by sector representatives, who had contacted the government and proposed a different concept to better reflect the actions and functions of civil society-based organisations.

However, these conceptual re-orientations did not go unnoticed. The Left Party argued that the Bill was an ideological test and that the '... term civil society is an expression of bourgeois newspeak and a preparation of a different welfare model than we have, and which rests upon charity and voluntary forces' (Kulturutskottet 2009/10 KrU7, § 108). Also proponents of the Social democratic government made similar arguments and suggested that this re-orientation away from the established term 'popular movement' was unnecessary (see Motion med anledning av prop 2009/10:Kr5). Above all, critics argued that non-profit and voluntary organisations should not be reduced to governmental subcontractors or forced into businesslike models.

Second, another illustration of a changing national agenda on state-NPV sector is the Agreement between the state and the NPV sector, installed in 2008. The Agreement was inspired by the English Compact and also highly nurtured by lobbying activities from various non-profit and voluntary organisations (Johansson and Johansson 2012; Reuter 2012). Scholars propose that the Agreement illustrates an orientation towards more liberal values and principles concerning the NPV sector's roles in welfare service production (ibid.). Like its English role model, the Swedish Agreement rests on a set of principles regarding the state and the sector's mutual roles and responsibilities. The Swedish Agreement sought to bridge previous divisions between service and expressive functions of non-profit and voluntary organisations. It furthermore emphasized the 'autonomy and independence' of the sector and the importance of continuity in the financial support to sector organisations. It also emphasized the role of the sector in offering a welfare system based on a diversity of service deliverers. Along with this, followed requests for some sort of quality control of services provided and improved organisational transparency.

The Agreement was not debated in Parliament and hence not widely discussed among political parties. It was however extensively debated within the sector. Some NPVOs criticized the government's ambition and maintained that a greater emphasis on service orientation would be an intrusion of their democratic function. Others were more optimistic and supportive of the government's ambition to encourage both service- and advocacy-oriented actors (see Johansson and Johansson 2012; Johansson et al. 2011). Once again, we encounter a conceptual re-orientation away from the concept of 'popular movement' as representatives of various NPV organisations and government officials put forward the concept of idea-based organisations. This reflected a trend towards diversity also within the sector: 
whereas some organisations continued to be voluntary, grassroots-based, others engaged in extensive service delivery activities and required degrees of organisational professionalization. A reference to 'idea-based' signified a common denominator uniting these organisations and it was envisioned that this concept would help overcome barriers between organisations of somewhat different characteristics. The agreement has, however, not been mandatory for local governments to implement, and the central government has not to any greater extent been pushing local governments to adapt to the changing national agenda.

Third, another illustration of a changing national agenda on state-NPV sector relations can be found in the Centre-Conservative government's efforts to promote a diversity of service providers. As mentioned this was an explicit priority and mainly framed in relation to providing more freedom of choice for customers, and only partly in relation to non-profit actors as potential providers of such services (SFS 2008:962; prop 2008/2009:29). The Act on freedom of choice (hereafter FCS) aimed to make public procurement procedures easier and to encourage diversification of non-statutory actors in local welfare services production. The main logic of the reform was to restrain the principle of price competition in public tenders. Instead welfare producers could seek accreditation for a local freedom of choice system, i.e. if the applying organisation was deemed eligible based on standards established by the authority, the organisation was granted a public contract to provide services for citizens. This reform hence did not strive to change neither conceptual orientation nor rules for engagement, but rather encourage a diversity of service providers in local welfare production. The reform now includes a wide range of welfare service areas such as elderly care and disability care, health- and medical care services and active labour market services. However, the Parliamentary debate did not address the reform as a matter of changing the preconditions for for-profit and non-profit organisations. The debate was primarily framed as a matter of public vs. market solutions and the parties in opposition (Social democrats, Left Party and Green party) were clearly against the reform (see Socialutskottets betänkande 2008/09:SoU5).

These changes combined provide contours of a changing national agenda on the role NPV organisations should play in the Swedish welfare state. It is obvious that one of the fault lines concerns the role of NPVOs as service provider. The idea of expanding the role and expectations of NPVOs from having primarily an expressive function to also/increasingly include a service function has caused fault lines within the sector itself. What emerges is thus a contested terrain of different positions among representatives of political parties that at least partially tend to follow a Right/Left divide. The Centre-Conservative government has been more prone to promote policies that seek to foster a service function, sometimes embedded in wider ambitions to promote more for-profit involvement in welfare services production. Proponents of the Social democratic party have been more inclined to reject such ambitions and instead put forward arguments in favour of a more classic model. However, considering that it is local governments that fund, design and implement welfare services it is evident that an investigation of how such contestations and fault lines play out in practice needs to be situated at the local level. The following sections will analyse how different positions are used in and what impact they have for local municipalities. 


\section{Political Positions and the Welfare Mix Model: The Local Level}

Changes in national policies have intensified an the academic debate on the degree to which there has been an actual turn towards a more profound and stronger service providing role for NPVOs in the Swedish welfare state. Many observers tend to agree that there is a greater expectation and usage of these organisations as producers of welfare services, but at the same time such patterns are hard to detect in official national statistics (see Wijkström and Einarsson 2006; Prop 2009/10:55, SCB 2010). Most sources, however, demonstrate a rapid expansion of for-profit providers in welfare delivery across the country. One of the most solid studies reveals that from early 2000 until 2010 there was a significant increase in number of employees in the private for-profit sector (both in absolute numbers and in relative terms) (Hartmann 2011). Numbers increased from approximately 38,000 in 2002 to almost 100,000 in 2010 (including the areas of elderly care, disability care, social services, child care services and regular education) (Svedberg and Olsson 2010). The expansion of private for-profit actors has been particularly evident in the areas of education and elderly care. The same study found that the rise of non-profit actors as services producers has been much slower (ibid.). Also other studies have made similar observations, confirming that the most profound change in Swedish welfare service production has been the tremendous growth of for-profit actors (e.g. Hjukström and Perkiö 2011). These figures indicate that it is-still-primarily public agencies that are involved in the delivery of welfare services, but that the share of for-profit actors is growing. Furthermore, figures at aggregate level suggest that NPVOs continue to play a limited role as producers of welfare services. These figures may however harbour variation at local level, and if so prompting questions whether the political position of local decision-makers play a decisive part in how new roles are attributed NPVOs.

A recently completed survey with representatives of Swedish municipalities gives us information on the degree to which local organisations are involved in service delivery, and to what extent a potentially new service function of NPVOs is debated at local level. In our study, municipal officials were asked a series of questions regarding local NPV sector policies, the extent to which they involved local NPVOs in local decision-making, local funding patterns etcetera. Considering the potentially conflicting functions of local NPVOs in the Swedish model (in terms of combining expressive and service-oriented functions), it is interesting to note that few municipalities had an overarching formal policy/strategy with regards to the sector and very few municipalities had given an elected politician a formal designated mandate for government-NPVO cooperation. Instead local policies and practices were mainly in the hands of local civil servants.

When asked to about what ambitions local governments had concerning the involvement of NPVOs, we found that most municipalities aimed to maintain an established relation to local NPVOs in the field of welfare services (stated by $39 \%$ of all municipalities, $N=85$ ) or to increase user involvement in local social services $(32 \%)$. It was considered of little interest to increase the mix of service providers, including the involvement of local NPVOs, in local welfare production 
(22\%), which indicates that local municipalities are generally satisfied with the division of labour between public and voluntary sector actors at local level. Although a stronger focus on the service providing function has been eminent in national debates and policy-making, it seems to have had less significance for local debates and policies. We furthermore found that the political contestations that were present in national debates had little significance at local level. Municipalities led by right-wing, left-wing, or coalition governments share similar views on the abovementioned propositions, yet with a slight overweight for right-wing led municipalities with regards to the aim to increase the mix of welfare services providers. A total of $47 \%$ of the right-wing led municipalities answering the question maintained that this was a key ambition with local policies, whereas only eleven $\%$ of the left-wing led governments and coalition led governments stated that such ambitions steered local policy-making $(N=46){ }^{2}$

This seems to suggest that in local policy-making, voluntary sector organisations are still mainly shouldering the responsibility of acting as a complement to public welfare services, and in our survey very few municipalities had a different stance on this (irrespective of political majority in the local municipality). When asked whether the services of NPVO functioned as a replacement to public welfare services, a clear majority of municipalities disagreed with that proposition and we found limited variation between various political majorities in local governments. Our findings should be read cautiously since they draw on a small N, nonetheless our sample covers a large share of all local governments indicating that the patterns and results in the study might have relevance also in relation to other local governments (Table 1).

The accounts based on the survey questionnaire to municipalities suggest a fairly stable role for NPVOs in local welfare service delivery. However, the picture changes slightly if we also include an analysis of what local municipalities actually do in relation to such local actors (and have done in recent years). Swedish local municipalities are the main funders of NPVOs in the social service field and account for approximately $70 \%$ of the organisations' total income. Other incomes tend to come from fees, sales of goods and services to actors other than the municipalities, and other forms of public incomes. The proportion of income coming from local government to NPVOs has been relatively stable over the years. However, it is important to note that there has been a gradual shift from grants to payments for purchased services (Johansson 2005, Danielsson et al. 2009). Grants here refer to the transfer of financial resources on non-commercial terms, e.g. in terms of organisational grants (basic support to an organisation based on defined criteria such as the number of members, the frequency of meetings, the number of department units, etcetera) and operational grants (funding related to fixed-term project or activity). Payments for purchased services refer to the provision of social services on commercial terms. These are based on public procurement contracts, e.g. in the case of care of the elderly and the care of the disabled, but it can also be payments for outsourced services on a 'spot market', for example when municipalities pay

\footnotetext{
${ }^{2}$ The bivariate analysis of correlation between the political majority and whether they agree with this statement turned out to be statistically significant (Pearson Chi-Square 0.022 sig. and Cramer's V 0.407).
} 
Table 1 Non-profit and voluntary organisations' functions in local welfare mixes

\begin{tabular}{lcccc}
\hline Political majority & Agree $(\%)$ & Neither agree nor disagree $(\%)$ & Disagree $(\%)$ & Total $\%(N)$ \\
\hline Non-profit and Voluntary organisations functions as a complement to the municipalities & welfare services \\
Right-wing & 85.7 & 8.6 & 5.7 & $100(35)$ \\
Coalition led & 87.5 & 12.5 & 0 & $100(16)$ \\
Left-Wing & 93.9 & 3.0 & 3.0 & $100(33)$ \\
Total & 89.3 & 7.1 & 3.6 & $100(84)$ \\
Non-profit and Voluntary organisations functions as a replacement to the municipalities welfare services \\
Right-wing & 8.3 & 16.7 & 75.0 & $100(36)$ \\
Coalition led & 12.5 & 6.3 & 81.3 & $100(16)$ \\
Left-Wing & 9.4 & 12.5 & 78.1 & $100(32)$ \\
Total & 9.5 & 13.1 & 77.4 & $100(84)$ \\
Non-profit and Voluntary organisations produce more welfare services based on municipality contracts \\
Right-wing & 19.4 & 29.0 & 51.6 & $100(31)$ \\
Coalition led & 14.3 & 0.0 & 85.7 & $100(14)$ \\
Left-Wing & 12.9 & 32.3 & 54.8 & $100(31)$ \\
Total & 15.8 & 25.0 & 59.2 & $100(76)$ \\
\hline
\end{tabular}

All answers have been recoded from completely agree, partly agree, neither agree nor disagree, partly disagree, disagree completely and do not know into above categories. Answers do not know, have been recoded as missing. As mentioned, we cannot find any significant correlations according to political majority and local positions. However, when having the five answer option, for the question 'Voluntary organizations functions as a replacement to the municipalities welfare services', Chi-square 0.044 sig. and Cramer's V 0.306 indicating a weak significant correlation

women's shelters for their expenses by way of a per-diem in conjunction with a new client.

The ratio between grants and payments can thus be seen as an illustration of changing policies vis-á-vis local NPVOs. If we look at the development between 2000 and 2012 as reported in the municipalitieś financial accounts, we find that both grants and payments to NPVOs (including associations and foundations) have increased considerably (see Table 2 below). The grants grew from 351 million to 506 million, an increase of $44 \%$ (about $20 \%$ in fix prices), and has remained more or less the same since 2010. Payments for purchased services have increased from 1.7 billion to 3.4 billion, an increase of $95 \%$ (about $50 \%$ in fix prices), which is a significantly greater increase. Payments for purchased services thus account for a much greater part of the municipal cash flow to the sector, for instance in 2012 a total of $87 \%$.

Moreover, when it comes to financial grants (the remaining $13 \%$ ), these have also been subject to an control and contract culture that has intensified, evident in changes to the terms of use and requests for evaluations. In sum, conditions for obtaining grants have come to resemble conditions that underline public procurements. Increasing shares of grants have been earmarked for specific target groups, 
Table 2 Grants and purchased services from Swedish municipalities to non-profit and voluntary organisations in the social service area

\begin{tabular}{llllll}
\hline & 2000 & 2005 & 2010 & 2011 & 2012 \\
\hline Grants (millions of SEK) & 351 & 447 & 491 & 511 & 506 \\
Grants per capita (SEK) & 39.51 & 49.4 & 52.15 & 53.89 & 52.95 \\
Purchased services (millions of SEK) & 1742 & 2251 & 3135 & 3320 & 3402 \\
Purchased services per capita (SEK) & 196.11 & 248.79 & 332.96 & 350.11 & 356.01 \\
\hline
\end{tabular}

Source Statistics Sweden. Kommunernas finansstatistik 2000-2012

specific activities or operations, and the local control and evaluations of the use of the grants have intensified (Danielsson et al. 2009; Johansson 2002, 2005). This implies that expectations related to organisations involved in the delivery of services are also embedded in financial transactions, and not only visible in policies per se. If we 'follow the money' it thus becomes obvious that local governments promote a service provider function, and assume organisational routines that tally with a degree of professionalization, through their financial relations with NPVOs.

But what factors might then explain this development, and furthermore, what factors might explain the extensive variation we find between municipalities regarding to what degree they enrolled voluntary sector organisations as service providers. As we recalculated the figures for Sweden (including all municipalities and for the year of 2012), the figures became approx. SEK 53 for grants and approximately SEK 356 for purchased services. The variation between municipalities was extensive both with regards to grants and payments for services: between SEK 0-289 per capita for grants and even more so for purchased social services, ranging between SEK 0-3056 per capita for the year of 2012. This is certainly a finding in itself, illustrating wide variation between municipalities.

Considering the different political positions that coloured the national agenda, one might expect that political majority at municipal level matters to this variation. However, to allow for even greater complexity we inserted additional independent variables into the regression analysis, regarding population size of the municipality and municipal type (urban, suburban, rural, etcetera, based on Statistics Sweden typologies). Our regression analysis suggests that the extensive variation between municipalities cannot be explained by local political majorities (i.e. right-wing, leftwing and coalition led local governments for the year of 2012). This includes differences regarding level of the grants (Adjusted $\mathrm{R}$ square $=0.003 ; p=0.974$ ) and the level of purchased services (Adjusted $R^{2}=0.007 ; p=0.080$ ). However, the factor 'municipal category' (rural, urban) gives significant explanation to some of the variation, both in terms of the level of grants per capita (Adjusted $R^{2}=0.070$ ) and the payments for purchased services per capita (Adjusted $R^{2}=0.061$ ). Moreover, we found that population size counts as an even more powerful explanatory factor. Municipalities with relatively large populations not only give higher grants and payments in total terms, but also give higher grants per 
capita (Adjusted $R^{2}=0.344$ ) and higher payments for purchased services per capita (Adjusted $R^{2}=0.105$ ).

These findings suggest that political majorities have little significance in explaining differences between municipalities. On the contrary, urban municipalities with high population levels spend considerably more (per capita) than rural municipalities with few inhabitants irrespective of political majority. A plausible interpretation is that a more elaborate service function for local NPVOs presupposes public demand and supply, e.g. both professionalized organisations that can provide services and that put pressure on local governments to pay for these services. Such a combination of demand and supply is most likely to be found in larger urban localities.

Whereas these observations are based on the analyses of local political positions vis à vis NPVOs, the picture becomes more complex if we also include a wider understanding of a welfare mix. The Act on freedom of choice systems was a cornerstone in the Alliance's ambitions to foster a greater diversity of service providers and to promote more extensive welfare mix and welfare pluralism, combining for-profit and non-profit actors. We do not have systematic statistics on the extent to which NPVOs have been part of these local welfare mix models. Yet, statistics show that a majority of Swedish municipalities have implemented and/or are about to implement local FCS. A total of $49 \%$ (143 municipalities) have implemented FCS within the social care services and $12 \%$ (36 municipalities) are about to do so (spring 2014). Among those that have not implemented this system, $13 \%$ are currently investigating a local FCS and $14 \%$ have taken a direct stance not to implement the FCS system. The remaining 34 municipalities have not yet taken a stance on the issue (therefore the total of municipalities reacted amounting to a total of 256) (see Table 3 below).

Whereas our initial investigations revealed little if any relevance of local political majorities, this seems to be an explicit feature of local governments' willingness to

Table 3 Status of freedom of choice systems in Swedish municipalities

\begin{tabular}{|c|c|c|c|c|c|c|}
\hline & & \multicolumn{5}{|c|}{ Percentage municipalities "reacting to" FCS } \\
\hline & & $\begin{array}{l}\text { FCS } \\
\text { implemented } \\
(\%)\end{array}$ & $\begin{array}{l}\text { FCS to be } \\
\text { implemented } \\
(\%)\end{array}$ & $\begin{array}{l}\text { FCS under } \\
\text { investigation } \\
(\%)\end{array}$ & $\begin{array}{l}\text { Decision not to } \\
\text { implement } \\
\text { FCS }(\%)\end{array}$ & $\begin{array}{l}\text { Total } \\
\%(\mathrm{~N})\end{array}$ \\
\hline \multirow{3}{*}{$\begin{array}{l}\text { Political } \\
\text { majority } \\
(2010-2013)\end{array}$} & $\begin{array}{l}\text { Right- } \\
\text { wing }\end{array}$ & 74 & 13 & 10 & 2 & $\begin{array}{r}100 \% \\
(136)\end{array}$ \\
\hline & Left-wing & 34 & 11 & 23 & 33 & $\begin{array}{c}100 \% \\
(80)\end{array}$ \\
\hline & $\begin{array}{l}\text { Right- } \\
\text { Left } \\
\text { coalition }\end{array}$ & 38 & 23 & 13 & 28 & $\begin{array}{c}100 \% \\
(40)\end{array}$ \\
\hline Total & & 56 & 14 & 15 & 16 & $\begin{array}{r}100 \% \\
(256)\end{array}$ \\
\hline
\end{tabular}

Source Swedish Association of Local and Regional Authorities (SKL), 2014 
implement the reform. Reflecting the political and ideological nature of this reform, very few of the Right-wing led local governments have decided not to introduce the FCS and almost everyone has taken a stance on the national reform. We also find a clear significant correlation between political majority and the implementation of FCS (Pearson Chi-Square 0.000 sig. and Cramer's V 0.341). Arguably, there is a link between political majority and the implementation of a local FCS, as Alliance led municipalities are more inclined to implement such systems and Left-wing governments are more inclined to take a stance not to implement (and they are also overrepresented when it comes to those municipalities that have not 'reacted' at all).

\section{Conclusion}

The Swedish Social democratic tradition of publicly funded, administered and delivered welfare services is being challenged as a move towards a greater mix in welfare production has been evident in national policy-making for some time. This includes the introduction of a welfare market model, which features a diverse set of service providers including public, private for-profit and NPV organisations.

At national level, we identify ideological cleavages and manifest contestations between Right-Wing and Left-Wing positions concerning the role of NVPOs in the Swedish welfare state. These concern an increasing emphasis on a service function rather than a more traditional expressive, voice function. The contestations manifest themselves in a new discourse and concepts used by the Right-Wing that acknowledge NPVOs as important contributors to the welfare society. A new discourse, conceptual innovation, followed by the new Agreement between the state and the NPV sector implies a re-drawing of boundaries between the public sector and the organised civil society. Left-Wing proponents on the other hand argue that new concepts primarily signify a move towards businesslike models that would force voluntary organisations to adapt to market logics. The move from expressive to service function may jeopardize the independent position and democratic role of the sector. The disputes related to new roles and expectations of NPVOs vis à vis the state and welfare provision is furthermore linked to even more profound disagreements regarding the role of market-based service provision in the Swedish welfare state: here we find clear ideological differences, articulated on a continuous basis at national, party political level.

While these ideological cleavages structure the national arena, local level politics is not politicized to the same extent or driven by similar political and ideological concerns. Our study illustrates that, when it comes to political disputes concerning the role of NPVOs as welfare service providers there are few if any political disputes. So, in spite of a move towards a more service-oriented function associated with NPVOs, expressed in national politics, this does not seem to be a contested issue at local level: we find that at municipal level irrespective of political majority, NPVOs are ascribed a complementary function to public welfare. However, when we explore how municipalities relate to NPVOs in practice-using financial relations as indicator-we can detect a somewhat different pattern. Overall, we notice a change in financial arrangements towards NPVOs, with an increase in 
grants as well as payments for purchased services. We furthermore notice variation across municipalities regarding grants and payments for services, yet our analysis does not support the idea that variation can be explained by local political majority. Rather, we suggest that a municipal categorization based on urban/rural characteristics and population size count as more powerful explanatory factors. Nonetheless, the main ideological cleavage at local level regards the involvement on for-profit actors in local welfare mix models. It is here the main ideological contestations that take place.

These results prompt further questions. How should we interpret the fact that although issues regarding a changing role of NPVOs are not articulated as political, and in particularly not politically contested, at local level, there is a noticeable change in practice in how municipalities relate to the sector? On the one hand we may argue that the change does not imply that NPVOs take on new roles as service providers to the extent that it threatens a traditional division of labour between public and civil society sectors, and hence a Social democratic model logic Taking a bold interpretation, one may also contemplate that local politicians hesitate to venture into policy-making that prescribes a radical change in the involvement of NPVOs as service providers, since this is likely to provoke contestations both within the NPV sector, and among political parties. Another plausible interpretation is evidently that the main ideological debate regards the current liberalization of the Swedish model of welfare, in terms of welfare mix model that includes NPVOs and even more so for-profit actors.

The analyses and ensuing discussions offered in this paper contribute towards an analytical model that can help us to tease out the complexities underpinning existing and envisioned roles and expectations related to NPVOs as welfare service providers. Such an analytical model should reflect both political tradition and politically contested terrains regarding NPVOs and welfare mix models. It should furthermore allow for empirical focus that includes both national and local levels: it is at the interstice between these different understandings of ideology and geographical arenas that we can find explanations for how NPVOs are positioned as well as opportunities for new politics of engagement led by civil society actors or other stakeholders.

Acknowledgment The support from FORTE (2012-0686: 'Citizens' voice or local government contractors: the role of NPOs in local welfare societies') and The Swedish Research Council (VR, 2011-6699: between voice and service: the role of voluntary organizations in a changing welfare society) is gratefully acknowledged.

Open Access This article is distributed under the terms of the Creative Commons Attribution 4.0 International License (http://creativecommons.org/licenses/by/4.0/), which permits unrestricted use, distribution, and reproduction in any medium, provided you give appropriate credit to the original author(s) and the source, provide a link to the Creative Commons license, and indicate if changes were made.

\section{References}

Amnå, E. (2006a). Playing with fire? Swedish mobilization for participatory democracy. Journal of European Public Policy, 13(4), 587-606.

Amnå, E. (2006b). Still a trustworthy ally? Civil society and the transformation of Scandinavian democracy. Journal of Civil Society, 2(1), 1-20. 
Andreotti, A., Mingione, E., \& Polizzi, A. (2012). Local welfare systems: A challenge for social cohesion. Urban Studies, 49(9), 1925-1940.

Ascoli, U. \& Ranci, C. (2002). The context of new social policies in Europe, In: Ascoli \& Ranci (Eds.). Dilemmas of the welfare mix. London: Kluwer Press.

Bode, I. (2006). Disorganized welfare mixes: voluntary agencies and new governance regimes in Western Europe. JESP., 16(4), 346-359.

Bozzini, E., \& Enjolras, B. (2012). Governing ambiguities: new forms of local governance and civil society. Baden-Baden: Nomos-Verl.-Ges.

Declaration of government, October 2006.

Dir. 2005:117, Den statliga folkrörelsepolitiken i framtiden.

EESC. (2012). The impact of the crisis on civil society organisations in the EU-Risks and opportunities. Brussels: European Economic and Social Committee.

Esping-Andersen, G. (1990). The Three Worlds of Welfare Capitalism. London: Palgrave Macmillan.

Esping-Andersen, G. (1999). Social Foundations of Postindustrial Economics. Oxford: Oxford University Press.

Evers, A. (1995). Part of the welfare mix: The third sector as an intermediate area. Voluntas, 6(2), 159-182.

Evers, A., \& Laville, J.-L. (Eds.). (2004). The third sector in Europe. Cheltenham: Edvard Elgar Press.

Featherstone, D, Ince, A., Mackinnon, D., Strauss, K. \& Cumbers, A. (2012) Progressive localism and the construction of political alternatives. Transactions of the Institute of British Geographers, 37(2), $1-6$.

Hartmann, L. (2011). Konkurrensens konsekvenser. Stockholm: SNS förlag.

Henriksen, L. S., Smith, S. R., \& Zimmer, A. (2011). At the eve of convergence? transformations of social service provision in Denmark, Germany, and the United States. Voluntas, 23(2), 458-501.

Hjukström, S., \& Perkiö, H. (2011). Den offentliga marknaden. Stockholm: Dagens Samhälle.

Johansson, S. (2002). Sociala ideella organisationer-som kommunerna ser dem. Norstedts: Socialstyrelsen. Stockholm.

Johansson, S. (2005). Ideella mål med offentliga medel. Förändrade förutsättningar för ideell välfärd. Stockholm: Sober Förlag.

Johansson, H. \& M. Johansson (2012). From a Liberal to a Social Democratic welfare state: the translation of the UK Compact into a Swedish context', Nonprofit Policy Forum, 3(2), Art. 6.

Johansson, H., Kassman, A., \& Scaramuzzino, R. (2011). Staten och det civila samhällets organisationer i ett föränderligt välfärdssamhälle. Kansliet för överenskommelsen: Perspektiv på en överenskommelse. Stockholm.

Kazepov, Y. (2008). The subsidiarization of social policies: actors, processes and impacts. European Societies, 10(2), 247-273.

Kazepov, Y. (2010). Rescaling social policies: towards multilevel governance in Europe. Surrey: Ashgate.

Kendall, J. (2010). Bringing ideology back in: The erosion of political innocence in English third sector policy. Journal of Political Ideologies, 15(3) 241-258.

Kendall, J., \& Deakin, N. (2010). Editorial: Political ideologies and the third sector. Journal of Political Ideologies., 15(3), 221-225.

Kröger, T. (2011). Retuning the Nordic welfare municipality. International Journal of Sociology and Social policy, 31(3/4), 148-159.

Kulturutskottets betänkande, 2009/10 KrU7, § 108.

Lewis, J. (2005). New Labour's approach to the voluntary sector: Independence and the meaning of partnership. Social Policy \& Society., 4(2), 121-131.

Lundström, T. \& F. Wijkström (2012) Från röst till service: Vad hände sedan?. In Wijkström, F. (Ed.) Civilsamhället $i$ samhällskontraktet: En antologi om vad som står på spel. Stockholm: European Society Press.

Lundström, T., \& Svedberg, L. (2003). The voluntary sector in a social democratic welfare state. The case of Sweden. Journal of Social Policy., 32(2), 217-238.

Lundström, T., \& Wijkström, F. (1997). The nonprofit sector in Sweden (p. 345). Manchester: Manchester University Press.

Danielsson A., Zetterberg, P., \& E. Amnå (2009). Bidrag till vad? - En kunskapsöversikt över effekter och metoder rörande statliga bidrag till ideella organisationer. Rapport till Ungdomsstyrelsen April 2009.

Motion med anledning av prop. 2009/10:55 En politik för det civila samhället. 
Papakostas, A. (2004), Civilsamhällets rationaliseringar. Arkiv för studier i arbetarrörelsens historia, 91, $19-45$.

Pinker, R. (1992). Making sense of the mixed economy of welfare. Social Policy \& Administration, 26(4), 273-284.

Proposition 2009/10:55, En politik för det civila samhället, Government Bill.

Reuter, M. (2012) Överenskommelsen som spegel och arena. In F. Wijkström (Ed) Civilsamhället $i$ samhällskontraktet: en antologi om vad som står på spel. Stockholm: European Civil Society Press, pp. 217-244.

Reuter, M., Wijkström, F. \& von Essen, J. (2012) Policy tools or mirrors of politics: governmentvoluntary sector compacts in the post-welfare state age, Nonprofit Policy Forum, 3(2).

Sabuni, H. \& G. Hägglund (2007), 'Satsning på ideella krafter löser landets vårdproblem', Dagens Nyheter, DN debatt 30 juni.

Salamon, L. (2010). Putting the civil society sector on the economic map of the world. Annals of Public and Coooperative Economics, 81(2), 167-210.

Salamon, L., \& Anheier, H. (1994). The Emerging Sector: An overview. Manchester: Manchester University Press.

Salamon, L., \& Anheier, H. (1996). The international classification of nonprofit organizations-revision 1. Working papers of The Johns Hopkins Comparative Nonprofit Sector Project, no. 19, The Johns Hopkins Institute for Policy Studies, Baltimore, MD.

Salamon, L. M., \& Anheier, H. K. (1997). Defining the nonprofit sector: A cross-national analysis. Manchester: Manchester University Press.

Salamon, L., \& Anheier, H. (1998a). Social origins of civil society: Explaining the nonprofit sector crossnationally. Voluntas, 9(3), 213-248.

Salamon, L., \& Anheier, H. (1998b). On developing comparative nonprofit-sector theory: A reply to Steinberg and Young, and Ragin. Voluntas, 9(3), 271-281.

Salamon, M. L., Sokolowski, S., \& List, R. (2003). Global Civil Society: An overview. Chicago: The John Hopkins University.

SCB (2010), Hushållens icke-vinstdrivande organisationer, en enkätundersökning under uppbyggnad. Bakgrundfakta. Ekonomisk statistik 2010:1. Stockholm: SCB.

Selle, P., \& Wollebaek, D. (2010). Why Social Democracy is not a civil society regime in Norway. Journal of Political Ideologies., 15(3), 289-301.

SFS 2008:962. Lag om valfrihetssystem.

Socialutskottets betänkande 2008/09: SoU5

SOU 2007:66, Rörelser $i$ tiden.

Steen-Johnsen, K., Eynaud, P., \& Wijkström, P. (2011). On Civil Society Governance: An Emergent Research Field. Voluntas, 22(4), 555-565.

Strachwitz, R., \& Zimmer, A. (2010). The third sector and political ideologies: unpacking relations between organized civil society and the state. Journal of Political Ideologies., 15(3), 273-287.

Svedberg, L., Olsson, och L-E. (2010). Voluntary Organisations and Welfare Provision in Sweden'. In A. Ewers \& A. Zimmer (Eds.) Third Society Organizations Facing Turbulent Environments. BadenBaden: Nomos Verlag.

Titmuss, R. M. (1958). Essays on the Welfare State. London: George Allen and Unwin.

Trägårdh, L. (2010). Rethinking the Nordic welfare state through a neo-Hegelian theory of state and civil society. Journal of Political Ideologies., 15(3), 227-239.

Trydegård, G.-B., \& Thorslund, M. (2010). One Uniform Welfare State or a Multitude of Welfare Municipalities? The Evolution of Local Variation in Swedish Elder Care. Social Policy \& Administration, 44(4), 495-511.

Wijkström, F., \& Einarsson, T. (2006). Från nationalstat till näringsliv? Det civila samhällets organisationsliv $i$ förändring. Stockholm: Handelshögskolan.

Wijkström, F., \& Lundström, T. (2002). Den ideella sektorn: organisationerna $i$ det civila samhället. Stockholm: Sober.

Wollebeak, D. \& Selle, P. (2008). A Social Democratic model of civil society, In B. Jobert \& B. KohlerKoch (Eds.). Changing Images of civil society. London: Routledge. 